\title{
ВИВЧЕННЯ ГІПОГЛІКЕМІЧНОЇ ДІЇ ФІТОЗАСОБУ, ЩО МІСТИТЬ СУХІ ЕКСТРАКТИ З ЛИСТЯ ШОВКОВИЦІ БІЛОЇ, СТУЛОК КВАСОЛІ ЗВИЧАЙНОЇ І ПАГОНІВ ЧОРНИЦІ ЗВИЧАЙНОЇ
}

Вступ. Цукровий діабет - це соціальна катастрофра, яка позбавляє життів мільйони людей, і найгіршою тенденцією є те, що дві третини з них мають працездатний вік. Незважаючи на те, що сучасний фрармацевтичний ринок представлений широким арсеналом лікарських засобів, які застосовують для профрілактики та лікування хворих на цукровий діабет, пошук нових гіпоглікемічних засобів $є$ актуальним завданням сучасної фрармації. Завдяки комплексу біологічно активних речовин у рослинах, фрітозасоби проявляють багатогранну дію на людський організм, забезпечуючи вплив на різні ланки розвитку діабету та його специфічних і неспецифрічних ускладнень при мінімальному ризику токсичних чи алергічних проявів, та можуть слугувати альтернативою для синтетичних цукрознижувальних препаратів.

мета дослідження - вивчити гіпоглікемічну дію фрітозасобу (комбінація сухих екстрактів з листя шовковиці білої Morus alba L., стулок квасолі звичайної Phaseolus vulgaris L., пагонів чорниці звичайної Vaccinium myrtillus L.).

Методи дослідження. Дослідження проводили на щурах-самцях лінії Вістар, яким внутрішньошлунково профрілактично вводили фрітозасіб упродовж 7 днів у різному дозуванні. Як рефреренс-препарати було використано: настій з лікарського збору "Арфразетин", суспензію таблеток "Меторормін". Визначали концентрацію глюкози у крові тварин натще (до та після введення відповідних засобів), а також за умов проведення орального тесту толерантності до глюкози.

Результати й обговорення. В усіх дослідних групах, тварини яких отримували фрітозасіб, спостерігали зниження базальної глікемії після семиденного профрілактичного введення, а також зменшення розвитку глікемії за умов проведення орального тесту толерантності до глюкози. Гіпоглікемічна дія фрітозасобу в дозуванні з розрахунку 100 мг/кг сухого екстракту з листя шовковиці білої є порівнюваною з дією препарату "Метформін" та достовірно перевищує дію настою з лікарського збору "Арфазетин".

Висновки. Отримані результати дослідження вказують на виражену гіпоглікемічну дію фрітозасобу, що містить сухі екстракти з листя шовковиці білої, стулок квасолі звичайної і пагонів чорниці звичайної. Подальше вивчення гіпоглікемічної дії досліджуваного фрітозасобу буде здійснено в обраному дозуванні - 3 розрахунку 100 мг/кг сухого екстракту з листя шовковиці білої.

КЛЮЧОВІ СЛОВА: цукровий діабет; сухий екстракт; шовковиця біла; чорниця звичайна; квасоля звичайна; оральний тест толерантності до глюкози.

ВСТУП. Цукровий діабет (ЦД) - це соціальна катастрофра, яка позбавляє життів мільйони людей. За останніми даними Міжнародної фредерації діабету, від ЦД страждають 425 млн мешканців Землі, а без об'єднаних і узгоджених заходів з подолання цієї епідемії до 2045 р. цисрра може збільшитися до 629 млн [1]. Згідно зі статистичною інфрормацією МОЗ України, станом на 01 січня 2017 р. в Україні офріційно зареєстровано понад 1,2 млн хворих на ЦД (без урахування непідконтрольних територій) [2]. Найгіршою тенденцією є те, що дві третини з них мають працездатний вік [1].

(с А. І. Дуб, І. М. Кліщ, Л. В. Вронська, І. П. Стечишин, 2018.
Цукровий діабет 2 типу належить до гетерогенних та багатофакторних захворювань, які розвиваються в надрах метаболічного синдрому тає причиною розвитку захворювань серцево-судинної системи, уражень нервів, очей та нирок [3]. Це найбільш поширений тип ЦД, на який припадає близько 90 \% усіх випадків хвороби [1].

Сучасний фрармацевтичний ринок представлений широким арсеналом лікарських засобів, які застосовують для профілактики та лікування хворих на ЦД [4]. Проте до ери відкриття інсуліну та синтетичних цукрознижувальних препаратів саме фрітотерапія була єдиним методом лікування хворих на ЦД, тому й на сучасному етапі 
використання лікарських рослин для боротьби із цією недугою не втратило свого сенсу [5].

Складний комплекс біологічно активних речовин у рослинах надає фітозасобам багатогранності дії на людський організм, забезпечуючи вплив на різні ланки розвитку ЦД та його специфрічних і неспецифрічних ускладнень при мінімальному ризику токсичних чи алергічних проявів [5, 6].

Враховуючи це, розробка нових препаратів рослинного походження для профрілактики та лікування ЦД $є$ актуальним завданням сучасної срармації.

Мета дослідження - вивчити гіпоглікемічну дію фітозасобу (комбінація сухих екстрактів 3 листя шовковиці білої Morus alba L. (ЕШ), стулок квасолі звичайної Phaseolus vulgaris L. (EK), пагонів чорниці звичайної Vaccinium myrtillus $L$. (EU)).

МЕТОДИ ДОСЛІДЖЕННЯ. Дослідження проводили на щурах-самцях лінії Вістар масою $(180 \pm 20)$ г з нормальним вуглеводним гомеостазом. Піддослідних тварин було поділено на групи (n=6): контрольна, тварини якої отримували воду дистильовану; дві ресреренс-групи, тваринам яких вводили настій з лікарського збору "Арсразетин" (12 мл/кг) та суспензію препарату "Меторормін" (150 мг/кг) відповідно; п'ять дослідних груп, тварини яких одержували водні розчини фрітозасобу (ФЗ). Дозування останнього в цих дослідних групах - 50, 75, 100, 150, 200 мг/кг сухого екстракту з листя шовковиці білої. При розрахунку доз рефреренс-препаратів брали до уваги коефріцієнт видової витривалості за Ю. Ю. Риболовлєвим [7].

Відповідні засоби вводили тваринам внутрішньошлунково за допомогою тонкого металевого атравматичного зонда перед ранковим годуванням упродовж 7 днів.

Кров для досліджень отримували 3 хвостової вени щурів шляхом дистальної резекції хвоста. Концентрацію глюкози у крові тварин визначали натще, щоб уникнути впливу їжі на всмоктування досліджуваних засобів. Перше визначення здійснювали до початку експерименту, а друге після семиденного введення відповідних розчинів. Крім того, на 7 день, через 1 год після введення засобів, тварин усіх груп піддавали "глюкозному навантаженню" шляхом внутрішньошлункового введення $40 \%$ розчину глюкози 3 розрахунку глюкози 3 г/кг маси [7]. Через 30, 60, 90, 120 та 180 хв після "глюкозного навантаження" біосенсорним електрохімічним методом за допомогою тест-смужок та глюкометра "АссиChek Performa Nano" визначали концентрацію глюкози у крові щурів усіх груп.
Усі маніпуляції було проведено відповідно до загальних етичних принципів експериментів на тваринах, регламентованих положеннями Європейської конвенції про захист хребетних тварин, що використовуються для дослідних та інших наукових цілей (European convention for the protection of vertebrate animals used for experimental and other scientific purposes, Страсбург, 1986 р., зі змінами, 1998 р.) і Законом України "Про захист тварин від жорстокого поводження" (від 15.12.2009 р. № 1759-VI), та Директиви Європейського Союзу 2010/10/63 EU щодо експериментів на тваринах.

Статистичну обробку отриманих результатів проводили методами варіаційної статистики 3 використанням U-критерію Манна-Уїтні й критерію Стьюдента за допомогою комп'ютерних програм IBM SPSS Statistica v.10.1 та MS Excel 2010 і представляли у вигляді порівняльних таблиць із результатами різних груп. Для оцінки вірогідності отриманих результатів приймали рівень значущості $p \leq 0,05$.

РЕЗУЛЬТАТИЙ ОБГОВОРЕННЯ. РеЗУЛЬТаТИ дослідження впливу профрілактичного семиденного введення засобів тваринам дослідних і референс-груп наведено в таблиці 1. Враховуючи те, що концентрація глюкози натще у тварин різних груп дещо відрізнялася, для об'єктивної оцінки гіпоглікемічної дії було розраховано відсоток зниження концентрації глюкози у крові щурів натще порівняно 3 вихідним рівнем у кожній групі зокрема (рис. 1). У тварин вказаних груп спостерігали зменшення рівня базальної глікемії порівняно з вихідними показниками, що свідчить про виражену гіпоглікемічну активність засобів. Так, у групі щурів, які отримували ФЗ із розрахунку 50 мг/кг ЕШ, рівень глюкози в крові тварин натще був достовірно нижчим від показника контрольної групи на 18,5%. При збільшенні дози ФЗ спостерігали подальшу тенденцію до зменшення рівня глюкози та посилення гіпоглікемічної дії, і вже у групі тварин, яким вводили

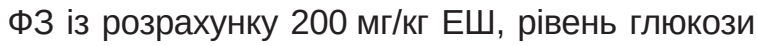
достовірно знизився на 27,0 \% порівняно 3 показником контрольної групи (табл. 1).

У дослідних групах, тваринам яких вводили Ф3 із розрахунку 50 та 75 мг/кг ЕШ відповідно, гіпоглікемічний ефрект семиденного профрілактичного введення достовірно не відрізнявся від такого ж ефректу в ресреренс-групі, тварини якої отримували арфазетин. Гіпоглікемічна дія ФЗ при дозуванні ЕШ 100, 150, 200 мг/кг була достовірно вищою на 6,9, 7,8 та 8,7 \% відповідно порівняно $з$ дією арфазетину. Базальна глікемія у тварин дослідних груп після семиденного введення ФЗ із розрахунку 100, 150, 200 мг/кг ЕШ 
Таблиця 1 - Результати визначення рівня глюкози у крові тварин натще на початку дослідження та після семиденного профрілактичного введення засобів

\begin{tabular}{|c|c|c|c|}
\hline \multirow{2}{*}{\multicolumn{2}{|c|}{ Група тварин }} & \multicolumn{2}{|c|}{ Концентрація глюкози натще, ммоль/л } \\
\hline & & вихідні дані & на 7 день експерименту \\
\hline \multicolumn{2}{|l|}{ Контрольна } & $4,98 \pm 0,07$ & $4,85 \pm 0,06$ \\
\hline \multirow[t]{2}{*}{$\begin{array}{l}\text { Рефреренс-групи, } \\
\text { які отримували: }\end{array}$} & 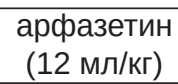 & $4,97 \pm 0,04$ & $3,92 \pm 0,04$ \\
\hline & $\begin{array}{c}\text { метформін } \\
(150 \mathrm{Mr} / \mathrm{k} \text { ) }\end{array}$ & $5,02 \pm 0,07$ & $3,50 \pm 0,06$ \\
\hline \multirow{5}{*}{$\begin{array}{l}\text { Дослідні, які отримували } \\
\text { Ф3, що містить ЕШ: }\end{array}$} & $50 \mathrm{Mг} / \mathrm{кг}$ & $4,73 \pm 0,07$ & $3,73 \pm 0,09$ \\
\hline & $75 \mathrm{мг/ \textrm { } г ~}$ & $4,63 \pm 0,06$ & $3,52 \pm 0,05$ \\
\hline & $100 \mathrm{Mг/кг}$ & $4,87 \pm 0,10$ & $3,50 \pm 0,04$ \\
\hline & $150 \mathrm{Mг} / \mathrm{k}$ & $4,90 \pm 0,10$ & $3,48 \pm 0,09$ \\
\hline & $200 \mathrm{Mг} / \mathrm{Kг}$ & $4,82 \pm 0,11$ & $3,38 \pm 0,08$ \\
\hline
\end{tabular}

Примітка. Тут і в таблиці 2:

1. Кількість тварин у групі (n) становить 6.

2. Оскільки в наукових джерелах не зустрічається досліджуваних показників у нормі в цього виду тварин, за норму було взято показники контрольної групи.

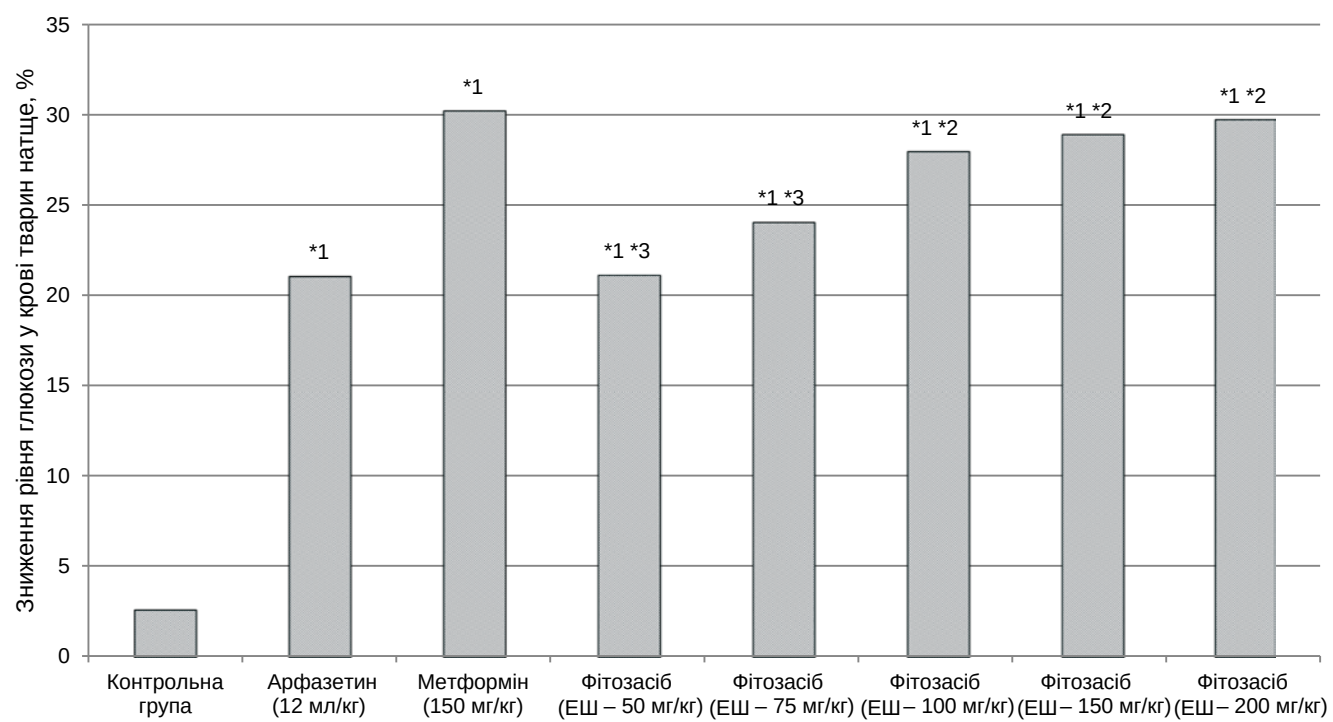

Рис. 1. Результати визначення рівня глюкози у крові тварин натще після семиденного профрілактичного введення засобів.

Примітка. *1 - достовірно відносно контрольної групи;

*2 - достовірно відносно тварин ресреренс-групи, які отримували арфразетин;

*3 - достовірно відносно тварин ресреренс-групи, які отримували меторормін

достовірно не відрізнялася від показника щурів рефреренс-групи, які отримували меторормін.

При обробці результатів дослідження гіпоглікемічної дії ФЗ за умов проведення орального тесту толерантності до глюкози врахували те, що концентрація глюкози у крові натще в дослідних групах відрізнялася, тому всі абсолютні значення (табл. 2) було переведено у відносні за 100 \% для кожної групи взято концентрацію глюкози у крові її тварин перед проведенням орального тесту толерантності до глюкози (рис. 2).

Внаслідок "глюкозного навантаження" рівень глюкози у крові тварин контрольної групи зростав на 53,3, 61,6, 54,4, 32,5 \% через 30, 60, 90, 120 хв відповідно від початку експерименту та повертався до вихідного рівня через 180 хв.
При введенні усіх дозувань ФЗ спостерігали зниження рівня глюкози у крові тварин порівняно з контрольною групою, що підтверджує його виражену гіпоглікемічну активність.

При застосуванні ФЗ у дозуванні, що містить 50 мг/кг ЕШ, гіпоглікемічна дія достовірно не відрізнялася від дії арфразетину через 30 та 60 хв, проте через 90 і 120 хв після “глюкозного навантаження" достовірно перевищувала останню на 9,4 та 6,8 \% відповідно. Ефрект зниження рівня глюкози внаслідок профілактичного введення Ф3 у дозуванні, що містить 75 мг/кг ЕШ, достовірно перевищував ефрект ардразетину на 6,1, 10,5 та 12,1 \% через 30, 60 і 90 хв відповідно.

Починаючи з дозування Ф3 із розрахунку 100 мг/кг ЕШ, гіпоглікемічний ефект у тварин дослідних груп достовірно не відрізнявся від 
Таблиця 2 - Результати визначення рівня глюкози за умов проведення орального тесту толерантності до глюкози після семиденного профілактичного введення засобів

\begin{tabular}{|c|c|c|c|c|c|c|c|}
\hline \multirow{2}{*}{\multicolumn{2}{|c|}{ Група тварин }} & \multirow{2}{*}{$\begin{array}{c}\text { Концентрація } \\
\text { глюкози натще, } \\
\text { ммоль/л }\end{array}$} & \multicolumn{5}{|c|}{$\begin{array}{c}\text { Концентрація глюкози у крові тварин } \\
\text { після “глюкозного навантаження”, ммоль/л }\end{array}$} \\
\hline & & & 30 XB & 60 XB & $90 \times \mathrm{B}$ & 120 XB & 180 хВ \\
\hline \multicolumn{2}{|l|}{ Контрольна } & $4,85 \pm 0,07$ & $7,43 \pm 0,14$ & $7,83 \pm 0,11$ & $7,48 \pm 0,09$ & $6,42 \pm 0,09$ & $4,83 \pm 0,04$ \\
\hline \multirow{2}{*}{$\begin{array}{l}\text { Референс- } \\
\text { групи, які } \\
\text { отримували: }\end{array}$} & 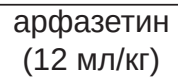 & $3,92 \pm 0,04$ & $5,08 \pm 0,05$ & $5,38 \pm 0,06$ & $5,32 \pm 0,05$ & $4,88 \pm 0,05$ & $3,98 \pm 0,04$ \\
\hline & $\begin{array}{l}\text { метфрормін } \\
(150 \mathrm{Mr} / \mathrm{kr})\end{array}$ & $3,50 \pm 0,06$ & $4,13 \pm 0,07$ & $4,38 \pm 0,06$ & $4,27 \pm 0,05$ & $3,90 \pm 0,06$ & $3,43 \pm 0,08$ \\
\hline \multirow{5}{*}{$\begin{array}{l}\text { Дослідні групи, } \\
\text { які отримували } \\
\text { Ф3, що містить } \\
\text { ЕШ: }\end{array}$} & $50 \mathrm{Mr} / \mathrm{kг}$ & $3,73 \pm 0,09$ & $4,77 \pm 0,06$ & $4,92 \pm 0,07$ & $4,72 \pm 0,10$ & $4,40 \pm 0,07$ & $3,77 \pm 0,06$ \\
\hline & $5 \mathrm{Mr} / \mathrm{Kr}$ & $3,52 \pm 0,05$ & $4,35 \pm 0,03$ & $4,47 \pm 0,04$ & $4,35 \pm 0,05$ & $4,15 \pm 0,06$ & $3,57 \pm 0,05$ \\
\hline & $100 \mathrm{Mr} / \mathrm{K} \Gamma$ & $3,50 \pm$ & $4,18 \pm 0,05$ & $4,28 \pm 0,03$ & $4,17 \pm 0,05$ & $3,88 \pm 0,05$ & $3,45 \pm 0,04$ \\
\hline & $150 \mathrm{Mг} / \mathrm{Kг}$ & & $4,20 \pm 0,07$ & 4,30 & $4,18 \pm 0,03$ & $3,97 \pm 0,06$ & $3,50 \pm 0,03$ \\
\hline & $200 \mathrm{Mг} / \mathrm{Kг}$ & $3,45 \pm 0,06$ & $4,15 \pm 0,06$ & $4,18 \pm 0,04$ & $4,08 \pm 0,06$ & $3,93 \pm 0,07$ & $3,52 \pm 0,03$ \\
\hline
\end{tabular}

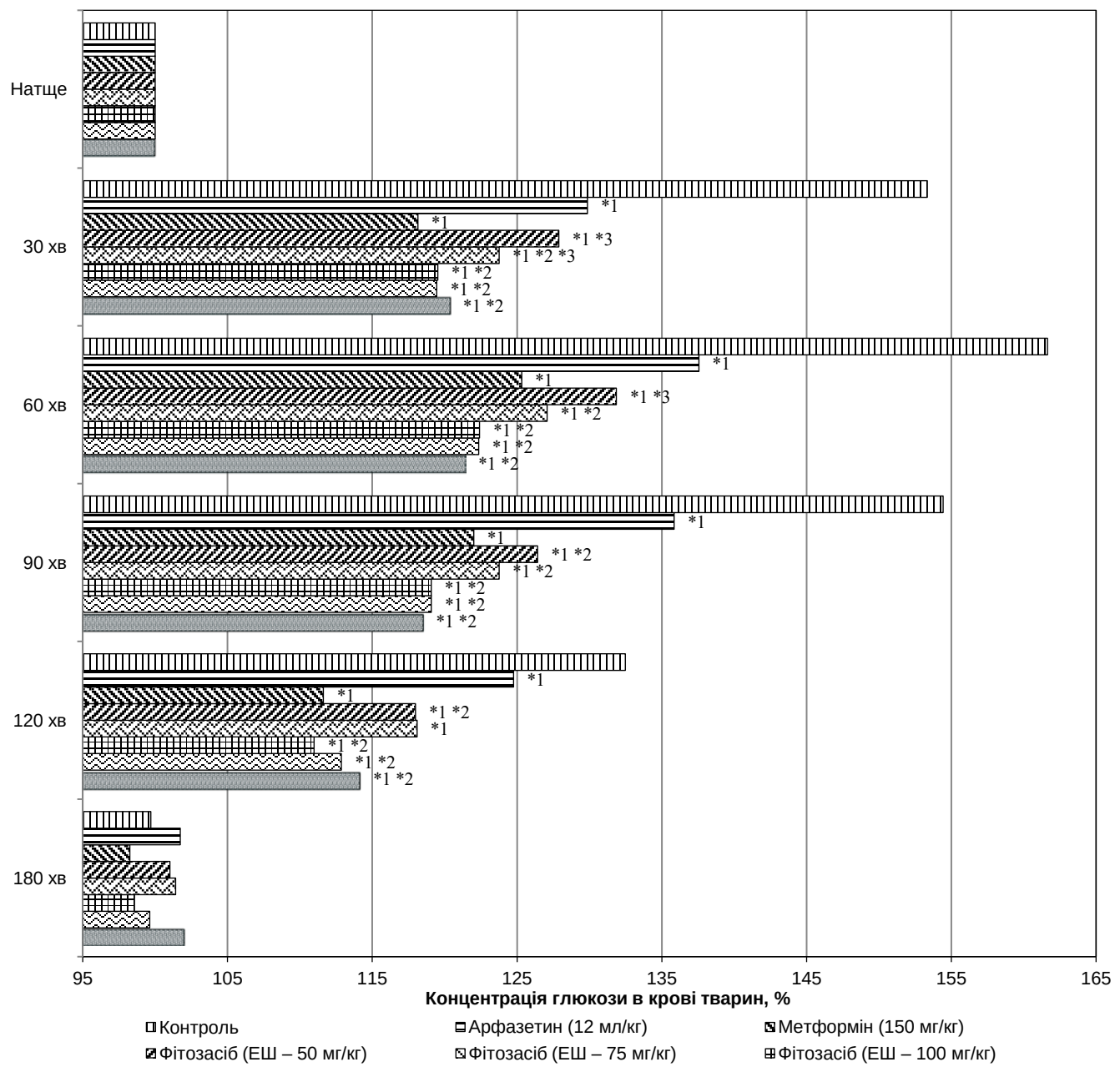

Рис. 2. Результати проведення орального тесту толерантності до глюкози після профрілактичного семиденного застосування вибраних засобів.

Примітка. *1 - достовірно відносно контрольної групи;

*2 - достовірно відносно тварин референс-групи, які отримували арфазетин;

*3 - достовірно відносно тварин референс-групи, які отримували метформін.

есректу метформіну та достовірно перевищував есрект арсразетину, а саме: через 30, 60, 90, 120 хв концентрація глюкози в крові тварин, яким вводили ФЗ у дозуванні 100 мг/кг ЕШ, була нижчою на $10,3,15,1,16,8,13,8 \%$ відповідно відносно арфразетину.
Зважаючи на те, що досліджуваний ФЗ бажано застосовувати довготривало, а в деяких випадках - хронічно, для уникнення можливих контрінсулінових реакцій, які можуть виникати при перевищенні дозування цукрознижувальних засобів [7], раціональним є застосування Ф3 із 
розрахунку 100 мг/кг ЕШ. Отже, при подальших дослідженнях гіпоглікемічної дії ФЗ на моделях експериментального діабету в щурів буде використано це дозування.

ВИСНОВКИ. 1. Отримані результати дослідження вказують на виражену гіпоглікемічну дію фрітозасобу, що містить сухі екстракти з листя шовковиці білої, стулок квасолі звичайної і пагонів чорниці звичайної.

2. Профрілактичне семиденне введення досліджуваного фрітозасобу з розрахунку 100 мг/кг сухого екстракту з листя шовковиці білої приводить до значного зниження рівня глюкози за умов проведення тесту "глюкозного навантаження". Його гіпоглікемічна дія є порівнюваною 3 гіпоглікемічним ефектом лікарського засобу "Меторормін" та достовірно перевищує гіпоглікемічну дію настою з лікарського збору "Арфазетин".

3. Подальше вивчення гіпоглікемічної дії досліджуваного фрітозасобу буде здійснено в обраному дозуванні - 3 розрахунку 100 мг/кг сухого екстракту з листя шовковиці білої.

\section{СПИСОК ЛІТЕРАТУРИ}

1. IDF Diabetes Atlas. - 8-th ed. - Brussels, Belgium : International Diabetes Federation, 2017. - Available at : http://www.diabetesatlas.org/.

2. Щорічна доповідь про стан здоров'я населення, санітарно-епідемічну ситуацію та результати діяльності системи охорони здоров'я України. 2016 рік / МОЗ України, ДУ “УІСД МОЗ України”. - К., 2017. - 516 с.

3. Про затвердження та впровадження медико-технологічних документів зі стандартизації медичної допомоги при цукровому діабеті 2 типу : наказ МОЗ України від 21.12.2012 р. № 1118 [Електронний ресурс]. - Режим доступу : http://old.moz.gov.ua/ua/portal/ dn_20121221_1118.html.

4. Ежнед М. А. Особливості цукрознижувальної дії сухого екстракту з коренів і кореневищ оману високого залежно від дози / М. А. Ежнед, Т. А. Грошовий,
О. М. Горошко // Фармац. часоп. - 2015. - № 3. C. $63-65$.

5. Савич А. О. Фармакологічне та фрітохімічне обгрунтування використання антидіабетичного рослинного збору в терапії цукрового діабету : дис. ... канд. фрармац. наук : 14.03.05 / Савич Альона Олександрівна. - Харків, 2017. - 209 с.

6. Горбулінська О. В. Біохімічні зміни в клітинах крові щурів за умов введення екстрактів та суспензій якона (Smallanthus sonchifolius Poepp. \& Endl.) за цукрового діабету 1-го типу : дис. ... канд. біол. наук : 03.00.04 / Горбулінська Олександра Вікторівна. Львів, 2017. - 207 с.

7. Доклинические исследования лекарственных средств / под ред. А. В. Стефранова. - К. : Авицена, 2002. -568 c.

\section{REFERENCES}

1. International Diabetes Federation (2017). IDF Diabetes Atlas. Retrieved from: http://www. diabetesatlas.org/.

2. MOZ Ukrainy, DU "UISD MOZ Ukrainy". (2017). Shchorichna dopovid pro stan zdorovia naselennia, sanitarno-epidemichnu sytuatsiiu ta rezultaty diialnosti systemy okhorony zdorovia Ukrainy. 2016 rik [Annual report on the health status of the population, the sanitary and epidemiological situation and the results of the health care system of Ukraine. 2016 year]. Kyiv [in Ukrainian].

3. Nakaz MOZ Ukrainy "Pro zatverdzhennia ta vprovadzhennia medyko-tekhnolohichnykh dokumentiv zi standartyzatsii medychnoi dopomohy pry tsukrovomu diabeti 2 typu" [Order of the Ministry of Health of Ukraine "On Approval and implementation of medical-technological documents for the standardization of medical aid in type 2 diabetes" No. 1118] [in Ukrainian].

4. Ezhned, M.A., Hroshovyi, T.A., \& Horoshko, O.M. (2015). Osoblyvosti tsukroznyzhuvalnoi dii sukhoho ekstraktu z koreniv i korenevyshch omanu vysokoho zalezhno vid dozy [Features of hypoglycemic effect of dry extract from the elecampane roots and rhizomes depending on the dose]. Farmatsevtychnyi chasopys Pharmaceutical Journal, (3), 63-65 [in Ukrainian].

5. Savych, A.O. (2017). Farmakolohichne ta fitokhimichne obhruntuvannia vykorystannia antydiabetychnoho roslynnoho zboru v terapii tsukrovoho diabetu [Pharmacological and phytochemical justification for the use of antidiabetic herbal collection in the treatment of diabetes]. Candidate's thesis. National University of Pharmacy, Kharkiv [in Ukrainian].

6. Horbulinska, O. V. (2017). Biokhimichni zminy v klitynakh krovi shchuriv za umov vvedennia ekstraktiv ta suspenzii yakona (Smallanthus sonchifolius Poepp. \& Endl.) za tsukrovoho diabetu 1-ho typu [Biochemical changes in rats peripheral blood cells under yacon (Smallanthus Sonchifolius Poepp. \& Endl.) water extracts and suspensions administration and under diabetes mellitus type 1]. Candidate's thesis. I. Franko Lviv Naional University [in Ukrainian].

7. Stefanov, A.V. (Ed.). (2002). Doklinicheskie issledovaniya lekarstvennykh sredstv [Preclinical studies of medicinal products]. Kiev: Avitsenna [in Russian]. 


\section{ИЗУЧЕНИЕ ГИПОГЛИКЕМИЧЕСКОГО ДЕЙСТВИЯ ФИТОСРЕДСТВА, КОТОРОЕ СОДЕРЖИТ СУХИЕ ЭКСТРАКТЫ ИЗ ЛИСТЬЕВ ШЕЛКОВИЦЫ БЕЛОЙ, СТВОРОК ФАСОЛИ ОБЫКНОВЕННОЙ И ПОБЕГОВ ЧЕРНИКИ ОБЫКНОВЕННОЙ}

\section{Резюме}

Вступление. Сахарный диабет - это социальная катастрофра, которая лишает жизней миллионы людей, и самой плохой тенденцией является то, что две трети из них имеют трудоспособный возраст. Несмотря на то, что современный фрармацевтический рынок представлен широким арсеналом лекарственных средств, применяемых для профилактики и лечения больных сахарным диабетом, поиск новых противодиабетических средств является актуальной задачей современной фрармации. Благодаря комплексу биологически активных веществ в растениях, фритосредства проявляют многогранное действие на человеческий организм, обеспечивая влияние на различные звенья развития диабета и его специфических и неспецифических осложнений при минимальном риске токсических или аллергических проявлений, и могут служить альтернативой для синтетических сахароснижающих препаратов.

Цель исследования - изучить гипогликемическое действие фитосредства (комбинация сухих экстрактов из листьев шелковицы белой Morus alba L., створок фрасоли обыкновенной Phaseolus vulgaris $L$., побегов черники обыкновенной Vaccinium myrtillus L.).

Методы исследования. Исследования проводили на крысах-самцах линии Buстар, которым внутрижелудочно профрилактически вводили фритосредство в течение 7 дней в разной дозировке. Как референс-препараты были использованы: настой из лекарственного сбора "Арфразетин", суспензия таблеток "Меторормин". Определяли концентрацию глюкозы в крови животных натощак (до и после введения соответствующих средств), а также в условиях проведения орального теста толерантности к глюкозе.

Результаты и обсуждение. Во всех опытных группах, животные которых получали фритосредство, наблюдали снижение базальной гликемии после семидневного профилактического введения, а также уменьшение развития гликемии в условиях проведения орального теста толерантности к глюкозе. Гипогликемическое действие фритосредства в дозировке из расчета 100 мг/кг сухого экстракта из листьев шелковицы белой является сопоставимым с действием препарата "Меторормин" и достоверно превышает действие настоя из лекарственного сбора "Арфразетин".

Выводы. Полученные результаты исследования указывают на выраженное гипогликемическое действие фритосредства, которое содержит сухие экстракты из листьев шелковицы белой, створок фрасоли обыкновенной и побегов черники обыкновенной. Дальнейшее изучение гипогликемического действия исследуемого фритосредства будет осуществляться в выбранной дозировке - из расчета 100 мг/кг сухого экстракта из листьев шелковицы белой.

КЛЮЧЕВЫЕ СЛОВА: сахарный диабет; сухой экстракт; шелковица белая; черника обыкновенная; фасоль обыкновенная; оральный тест толерантности к глюкозе.

A. I. Dub, I. M. Klishch, L. V. Vronska, I. P. Stechyshyn I. HORBACHEVSKY TERNOPIL STATE MEDICAL UNIVERSITY

\section{RESEARCH THE HYPOGLICEMIC ACTIVITY OF THE HERBAL REMEDY THAT CONTAIN DRY EXTRACTS OF WHITE MULBERRY LEAVES, COMMON BEAN SHELLS AND BLUEBERRY SPROUTS}

\section{Summary}

Introduction. Diabetes mellitus is a social catastrophe that deprives life of millions of people and the worst trend is that two-thirds of them are employable population. The search for new hypoglycemic agents is an actual problem task of modern pharmacy, despite the fact that the modern pharmaceutical market is represented by a broad drugs arsenal of used for the prevention and treatment of diabetes mellitus patients with. Due to a complex of biologically active substances in plants, herbal remedies manifest a multifaceted action on the human body, thus 
ensuring the influence on various stages of development of diabetes and its specific and non-specific complications, with a minimal risk of toxic or allergic influence and can be like an alternative for synthetic hypoglycaemic drugs.

The aim of the study - to research the hypoglycemic action of the herbal remedy (a combination of dry extracts of white mulberry (Morus alba L.) leaves, common bean (Phaseolus vulgaris L.) shells and blueberry (Vaccinium myrtillus L.) sprouts.

Research Methods. The research was conducted on Wistar male rats, which received intragastrically phyto remedies preventively during 7 days in different doses. An infusion of "Arphazetin", a suspension of tablets "Metformin" were used as reference substances. The determination of glucose concentration in the blood of animals was initiated (before and after usage of the appropriate extracts), as well as during the condition of the oral glucose tolerance test.

Results and Discussion. There was a decrease of basal glycemia after seven days of prophylactic administration, as well as a decrease of glycemia in the condition of an oral glucose tolerance test, in all experimental groups that received phyto remedies. The hypoglycemic action of a phyto remedies in a dosage of $100 \mathrm{mg} / \mathrm{kg}$ of dry extract of leaves of mulberry white is comparable to the effect of the drug "Metformin" and significantly exceeds the effect of infusion from the medicinal collection of "Arphasitin".

Conclusions. The obtained results of the study indicate the expressed hypoglycemic effect of phyto remedies, containing dry extracts of leaves of mulberry, leaflets of common bean and sprouts of blackberry common. Further study of the hypoglycemic effect of the investigated phyto remedies will be carried out in the chosen dosage at the rate of $100 \mathrm{mg} / \mathrm{kg}$ of dry extract leaves of mulberry white.

KEY WORDS: diabetes mellitus; dry extract; mulberry white; blackberry common; bean common; oral glucose tolerance test.

Отримано 12.07.18

Адреса для листування: А. І. Дуб, Тернопільський державний медичний університет імені І. Я. Горбачевського, майдан Волі, 1, Тернопіль, 46001, Україна, e-mail: dub_aih@tdmu.edu.ua. 